\title{
ІДЕНТИЧНІСТЬ ЯК КОМПЛЕКСНА ПРАВОВА КАТЕГОРІЯ
}

\author{
МЕДВІДЬ Олександра Олександрівна - аспірантка кафедри конституційного \\ права та порівняльного правознавства ДВНЗ «Ужгородський національний \\ університет»

В статье рассматривается вопрос идентичности личности. Акцентировано на идентичности как правовой категории. Категория «идентичность» прошла длительную эволющию своего содержательного наполнения, достигая свочми корнями в историю сочиогуманитарного знания. Сегодня концепт идентичности является междисииплинарной категорией и приобретает все большее значение и популярность в современной сочиальной мьсли.

Вълделенъ некоторьие современнъие видъ понимания идентичности личности. Указано, что в настоящее время актуализируется проблема вылделения правовой идентичности, которую понимают как персонализированное качество личности, отражающее состояние психологического усвоения собственного правового статуса. Национальная идентичность происходит через национальную самоидентификацию. Констатировано, ито актуальность приобретает такая категория, как гендерная идентичность. Указано, что ее сущность отражается в половом сознании, которое проявляется в различных взаимодействиях и отношениях к гендеру и полу, и их взаимосвязи, противоположности и проявлении. Гендерная идентичность не ограничивается лишь двойной структурой пола - мужчина, женщина. Она не статична, существует вдоль континиума и может со временем меняться.

Постановка проблеми

Антропологічні категорії визначають сучасну правову систему. Цінність гуманістичного устрою суспільства первинно проявляється через категорію прав та свобод людини. Усі правові явища, що icнують в цивілізованому суспільстві детерміновані для захисту, охорони людини, створення оптимальних умов для життедіяльності.

Впровадження в соціальну реальність потребують визнані гуманістичні цінності. Серед них однією з найбільш затребуваних юридичних категорій, проте науково недостатньо розробленою є проблема ідентичності людини. Нині немає єдиного погодженого юридичного обгрунтування розуміння ідентичності, її видів, співвідношення цього поняття з іншими, з-поміж яких статус особи, права та свободи особи тощо.

\section{Стан дослідження}

Проблеми розуміння внутрішнього «Я» в межах філософсько-правової науки досліджували С.Сливка, Т. Гарасимів, А.Токарська, О.Балинська та інші. Проблеми гендерної ідентичності через виокремлення гендерної рівності також слугували предметом аналізів науковців, зокрема К. Аевченко, А. Грибовська, I. Жаровська, I. Андрусяк, В. Черняхівська та інші. Проте залишаються невизначеними ряд теоретико-правових питань у сфері ідентичності.

Метою цієї статті є аналіз сутності ідентифікації та ідентичності як родового поняття та виокремлення деяких сучасних видів ідентичності. 


\section{Виклад основних положень}

Ідентичність $є$ категорією комплексною та комплементарною. Породжене це питання в межах психологічної науки, проте розширило свої межі на ряд інших соціальних наук, у тому числі формується і в межах правової науки. У першу чергу вказане зумовлено гуманізацією, демократизацією правової реальності. Проте, сьогодні вже слід говорити не просто про людиноцентризм, а про його наступні технократичні функції. Часто в науці вказане виокремлюють через поняття «перевідкриття гуманізму».

«Перевідкриття гуманізму» 3 моменту свого виникнення як філософської проблеми зазнало різних інтерпретацій. «Перевідкриття гуманізму» визначається як новий гуманізм, антигуманізм, постгуманізм, трансгуманізм, технокомунізм тощо. Ці модифікації корелюють із характеристикою сучасної епохи як епохи постєвропоцентризму, постнаціоналізму, постколоніалізму, постструктуралізму, постмодернізму, постіндустріалізму. У такому контексті обгрунтовуються положення про постнекласичну науку, постлюдство, постлюдину, кіборга. Ці концепції не можуть приховати вельми важливу обставину: гуманізм і його нові варіанти, нові модифікації у центр своїх роздумів висуває проблему людини, грунтуючись на різних світоглядних позиціях $[1,32]$.

Проблема особистісної ідентичності в сучасних роботах 3 психології, філософії та психіатрії стає однією 3 головних. Причиною цьому служить інтерес практиків до питання формування та становлення особистості в нашому суспільстві, що переживає період трансформації політичної, економічної та соціальної систем. Враховуючи факт незмінності закономірностей вікового розвитку, ми не можемо не брати до уваги вплив біологічних і соціально-психологічних умов, що супроводжують дорослішання людини, на дозрівання окремих структур психіки, у тому числі ідентичності.

Категорія «ідентичність» пройшла тривалу еволюцію свого змістовного наповнення, сягаючи своїм корінням в історію соціогуманітарного знання. Сьогодні концепт ідентичності є міждисциплінарною катего- рією і набуває все більшого значення і популярності в сучасній соціальній думці.

3 англійської (identity), французької (identite) та німецької (dentitat) мов перекладається як «тотожність», «автентичність», «особистість», «індивідуальність». Таким чином, категорія «ідентичність» тісно пов'язана не тільки $з$ поняттям «тотожності», але й із становленням поняття «індивідуальне» в різних дисциплінарних контекстах, а також 3 конституюванням у європейській традиції дискурсів «відмінності», «інакшості», «автентичності» та «іншого» [2].

Ідентичність слід сприймати як стан сформованої особистості, процес формування індивідуальних категорій називається ідентифікацією. На нього впливає низка чинників, що мають як внутрішній аспект, зокрема уподобання, установки, свідомість, знання, вірування тощо суб'єкта, так і зовнішні - у першу чергу, це те середовище, де формується особистість. На первинному етапі ідентифікації це сім'я, згодом соціальне середовище.

Загалом у науці погоджено, що ідентичність характеризує якісне самовизначення особистості, а ідентифікація - процесуальну сторону його розгортання.

Найбільш загальним для всіх соціальних наук є визначення ідентичності як активного процесу, який «відбиває уявлення суб'єкта про себе і супроводжується відчуттям власної безперервності, що дозволяє йому сприймати своє життя як досвід тривалості і єдності свідомості і дає можливість діяти послідовно». Ідентичність у цьому випадку виступає ознакою «входження» індивіда в соціальну позицію [3, с. 109].

У соціології П. Берк виокремлює «опорні пункти» ідентичності. Першим є соціальна роль, яка визначається локалізацією індивіда у соціальній структурі, і пов'язані з нею очікування. Другим виступає групова або категоріальна належність (чоловік, американець, член клубу), третім - специфіка індивіда як особи. Ідентичності рухомі саме тому, що постійно змінюються взаємовідносини між групами, системи обміну ресурсами, соціальні ролі [4].

Роль та значення ідентичності особи є доволі суттєвою. У широкому тлумаченні 


\section{Теорія, історія держави і права, конституційне право}

вона дозволяе узгодити, встановити умови оптимального «співжиття» зовнішнього та внутрішнього для окремої особистості.$\mathcal{\lambda}$. Нагорна переконує, що ідентичність є категорією, що здатна «поєднувати соціальне 3 індивідуальним - внутрішня солідарність людини з груповими ідеалами й стандартами перетворює іï саму в соціально-культурний феномен із певними якісними характеристиками» $[5$, с. 14].

Залежно від сфери виокремити можна різні види ідентичності.

У першу чергу, слід вести мову про соціальну ідентичність особи. Тобто ії здатність визначати внутрішнє «Я» та поєднувати, порівнювати, узгоджувати його із соціальною реальністю того середовища, в якому перебуває особа, з тим історичним часом, ментальними та суспільними правилами, цінностями, ідеологічними детермінантами.

Згодом науковий розвиток розширив своє розуміння цієї категорії на інші види ідентичності.

Зокрема, нині актуалізується проблема виокремлення правової ідентичності особи. Вперше на рівні комплексного дисертаційного дослідження це питання виокремила О. Парута. Вона детермінувала правову ідентичність «як персоналізовану якість особи, яка відображає стан психологічного засвоєння власного правового статусу і свідчить про усвідомлення особою своєї ролі у правовій системі» [6, с. 6]. Входження людини у правову реальність, ії соціалізація та ідентифікація є суттєвою сферою сучасної людини.

Пов’язаною 3 правовою 6 національна ідентичність, яка відбувається через національну самоідентифікацію, що «обумовлює вироблення оптимальних моделей соціально-економічного, суспільного й духовнокультурного розвитку в межах конкретної національної держави, що зумовлено культурними цінностями конкретного народу» [7, с.114].

Не меншої актуальності здобуває нині така категорія, як гендерна ідентичність.

Сутність їі відображається у статевій свідомості, котра проявляється у різних взаємодіях та ставленнях до гендеру та статі, й їх взаємозв’язку, протилежності та вияві.
Безумовно, саме соціалізація забезпечує культурне входження у зовнішній простір, де вияв статі та гендеру інших сприяє отриманню необхідного досвіду для особистості. Вказане зумовлює потребу розмежування понять гендер та стать.

Суддя Верховного суду США Антоні Скалія у рішенні спробував прояснити використання понять гендер і стать: «Алово гендер набуло нове і корисне додаткове значення культурних або оціночних характеристик у протиставлення фізичних характеристиках, на відміну від статі. Іншими словами, гендер стосовно статі - це те ж саме як жіночий, жіночний стосовно жіночої статі і чоловічий, мужній стосовно чоловічої статі» [8].

Стать - це біологічна характеристика особи. Стать належить до набору біологічних ознак у людей і тварин. Це пов'язано, у першу чергу, з фізичними та фізіологічними особливостями, включаючи хромосоми, експресію генів, рівень та функцію гормонів та репродуктивну / статеву анатомію. Зазвичай, стать класифікується як жіночий чи чоловічий, проте існують різні біологічні атрибути, що складають стать, та спосіб вираження цих атрибутів.

Гендер стосується характеристик жінок, чоловіків, дівчат та хлопців, яка мають соціальну характеристику. Це включає норми, поведінку та ролі, пов'язані з тим, щоб бути жінкою, чоловіком, дівчиною чи хлопчиком, а також стосунки між собою. Як соціальна конструкція гендер у різних соціальних групах, може змінюватися з часом.

Гендерна ідентичність не обмежується лише подвійною структурою статі - чоловік, жінка. Вона не статична, існуе вздовж континууму і може з часом змінюватися. Можливе значне розмаїття в тому, як люди та групи розуміють, переживають та виражають гендер через ролі, які вони позиціонують себе, реалізують покладені на них очікування, формують стосунки 3 іншими та складні способи інституціоналізації гендеру в суспільстві.

Зовнішній вигляд гендерної ідентичності людини, як правило, виражається поведінкою, одягом, стрижкою чи голосом i може відповідати соціальній визначеній 
поведінці та характеристикам, як правило, пов'язаним із чоловічою чи жіночою статтю.

Особливістю гендерної ідентичності є те, що ії не можна ототожнювати із статевою ідентичністю. Гендерна ідентичність належить до глибоко переживаного, внутрішнього та індивідуального досвіду людини, який може відповідати або не відповідати їі фізіології або призначеному статі при народженні.

Гендерні ролі в людини розвиваються під впливом виховного процесу, суспільних запитів та можуть різнитися залежно від держави та культурно-релігійних традицій. Становлення та генезис гендерної ідентичності як набір соціально зумовлених варіантів статевих ролей може різнитися в різних осіб. Тому можливий дисонанс між соціальними очікуваннями виконання соціальних ролей та внутрішнім сприйняттям статі.

Транссексуалізм, розлад статевої ідентичності проявляється сильною та стійкою міжстатевою ідентифікацією та прагненням адаптувати організм до бажаної статі шляхом гормональної та хірургічної зміни статі.

Порушення гендерної ідентичності можуть проявлятися різним ступенем тяжкості з раннього дитинства. Постраждалі діти виявляють бажання належати до протилежної статі або вважають, що вони насправді належать до неї. Вони демонструють характерну поведінку іншої статі, віддаючи перевагу партнерам по грі з протилежною статтю, а також одягу та іграм (включаючи рольові ігри), які зазвичай відносяться до неї. Вони відкидають усе, що вважається притаманним суспільству до їх біологічної статі. Зовнішній світ 3 його соціокультурними гендерними стереотипами сприймає їх як невідповідні до статі, з якою вони народились. Навіть маленькі діти інколи категорично відкидають або заперечують власну стать. Таке позиціонування крайнього ступеня може вважатися розладом гендерної ідентичності.

Діагноз базується на психіатричній оцінці та лікуванні на міждисциплінарному підході ендокринологами, хірургами та психіатрами. Проявити себе транссексуалізм може на різних вікових етапах, включаючи і дорослий вік. Вказане суттєво впливає на правовідносини, оскільки зачіпає медичні, соматичні права та цивільно-правові правовідносини з приводу унормування статусу людини відповідно до оновленої визначеної статі.

\section{Висновок}

Ідентичність характеризує якісне самовизначення особистості та як соціальна категорія характеризується комплексністю сфер. На сучасному етапі розмежовують національну ідентичність (процес ідентифікації людини з народом, його культурою та ментальними цінностями);

\section{Аітература}

Дениско А. М., Пилипенко С. Г., Кулікова I. I. Про перевідкриття гуманізму $B$ сник Харківського національного університету імені В. Н. Каразіна. Серія : Теорія культури і філософія науки. - 2013. - № 1083, Вип. 49(2). С. 32-35.

1. Пашина Н. П. Когнітивні карти феномену «ідентичність» Політологічні записки. 2013. № 7. URL: http://nbuv.gov.ua/UJRN/ Polzap_2013_7_9

2. Качанов Ю. А. Опыты о поле политики. М.: Институт экспериментальной социологии, 1994. 159 с.

3. Burke P. Identities and social structure Social psychology quarterly. L., 2004. Vol. 67, № 1. P. 5-15

4. Нагорна $\mathcal{~}$. П. Соціокультурна ідентичність: пастки ціннісних розмежувань. К. : ІПіЕНД ім. І. Ф. Кураса НАН України, 2011. 272 c

5. Парута О. В. Правова ідентичність особи : автореферат дисертації на здобуття наукового ступеня кандидата юридичних наук : 12.00.01 - теорія та історія держави i права; історія політичних і правових учень. Міністерство освіти і науки України, Національний університет «Аьвівська політехніка». Львів, 2017. 17 с.

6. Кремень В. Національна ідентичність як умова самоздійснення української нації Педагогічні інноващй: ідеї, реалї, перспективи. 2020. Вип. 1. С. 113-116

7. J.E.B. v. Alabama, 114 S. Ct. 1419, 1994 


\section{АНОТАЦІЯ}

у статті розглядається питання ідентичності особи. Акцентовано на ідентичності як правовій категорії. Категорія «ідентичність» пройшла тривалу еволюиію свого змістовного наповнення, сягаючи своїм корінням в історію соціогуманітарного знання. Съогодні конщепт ідентичності є міждисииплінарною категорією $і$ набуває все більшого значення $i$ популярності в сучасній сощіальній думиі.

Виокремлено деякі сучасні види розуміння ідентичності особи. Вказано, що нині актуалізується проблема виокремлення правової ідентичності, яку розуміють як персоналізовану якість особи, яка відображає стан психологічного засвоєння власного правового статусу. Національна ідентичність відбувається через начіональну самоідентифікацію. Констатовано, що актуальності здобуває така категорія, як гендерна ідентичність. Вказано, що ї сутність відображається у статевій свідомості, котра проявляеться у різних взаємодіях та ставленнях до гендеру та статі, $i$ їх взаємозв'язку, протилежності та прояві. Гендерна ідентичність не обмежується лише подвійною структурою статі - чоловік, жінка. Вона не статична, існує вздовж континууму $i$ може з часом змінюватися.

\section{DENTITY AS A COMPLEX LEGAL}

\section{CATEGORY}

The article considers the issue of identity. Emphasis is placed on identity as a legal category. The category of «identity» has undergone a long evolution of its content, reaching its roots in the history of socio-humanitarian knowledge. Today, the concept of identity is an interdisciplinary category and is becoming increasingly important and popular in modern social thought.

Some modern types of understanding of a person's identity are singled out. It is pointed out that now the problem of separation of legal identity, which is understood as a personalized quality of a person that reflects the state of psychological assimilation of one's own legal status, is actualizing. National identity occurs through national self-identification. It is stated that such a category as gender identity becomes relevant. It is stated that its essence is reflected in the sexual consciousness, which is manifested in various interactions and attitudes towards gender and sex, and their relationship, opposition and manifestation. Gender identity is not limited to the dual structure of sex - man, woman. It is not static, exists along a continuum and may change over time. 